\title{
Sixth-graders' Paintings for the U.S. Food Conservation Effort: A Qualitative Study
}

\author{
Jeremiah Clabough*
}

* The University of Alabama at Birmingham, School of Education, Birmingham, Alabama

E-mail: jclabou2@uab.edu

\section{Article Info}

Received: December 9, 2020

Revised: March 13, 2021

Accepted: April 10, 2021

$10.46303 / \mathrm{jcsr} .2021 .3$

\section{How to cite}

Clabough, J. (2021). Sixth-graders' Paintings for the U.S. Food Conservation Effort: A Qualitative Study. Journal of Curriculum Studies Research, 3(2), 148-168. https://doi.org/10.46303/jcsr.2021.3

\section{Copyright license}

This is an Open Access article distributed under the terms of the Creative Commons Attribution 4.0 International license.

https://creativecommons.org/licenses/by/4.0/

\section{ABSTRACT}

In this article, a research project is discussed that examines the political messages within the 12 paintings commissioned by the U.S. Food Administration to cause civilians during World War I to donate food for the war effort. Sixth grade students in my research project analyzed these paintings and then created their own painting based on arguments in Hoover's Food in War Speech on why U.S. civilians should donate for the food conservation effort. They conveyed in their paintings political messages found in the 12 paintings commissioned by the U.S. Food Administration. The findings from coding students' paintings and metacognitive writing pieces are discussed.

\section{KEYWORDS}

Visual primary sources; Herbert Hoover; U.S. Food Administration, Civic education; Inquiry-based teaching 


\section{INTRODUCTION}

Students encounter visual political messages on a daily basis. For example, political candidates and special interest groups create commercials with imagery to try and sway voters' decisions. The imagery employed in these commercials is designed to play on viewers' values, emotions, and beliefs (Mason, 2015). Social studies teachers need to utilize classroom activities for their students to critically analyze media tools in order to be critical consumers of political media messages (Sperry \& Baker, 2016). Social studies teachers can use visual primary sources from historical time periods to show how people attempted to convince citizens to support certain public policies.

In this article, a research project is discussed that examines the political messages within the 12 paintings commissioned by the U.S. Food Administration to cause civilians during World War I to donate food for the war effort. Sixth grade students in my research project analyzed these paintings and then created their own painting based on arguments in Hoover's Food in War Speech on why U.S. civilians should donate for the food conservation effort. Herbert Hoover's Food in War Speech and the series of 12 paintings commissioned by the U.S. Food Administration were used on days three and four were provided with the permission of the Herbert Hoover Presidential Library-Museum. These students conveyed in their paintings similar political messages to those found in the 12 paintings commissioned by the U.S. Food Administration.

Warfare changed during World War I. Industrialization in the latter part of the $19^{\text {th }}$ century in conjunction with technological improvements in weaponry led to World War I having high numbers of casualties. The destruction from this war made countries more dependent upon civilians on the home front to contribute donations and create needed goods for the war effort. When the United States entered World War I, its demands on the home front were greater. The U.S. was mobilizing for the war while also providing food supplies to its allies. Allied forces struggled to meet food supplies for their civilians and soldiers due to three years of war (Miller, 2018).

Herbert Hoover was charged with leading the U.S. Food Administration in large part due to his international successes as an engineer for various corporations with overseas projects (Nash, 1988, 1996). He made speeches around the U.S. to encourage civilian donations for the food conservation effort (Mullendore, 1941; Nash, 1996). Hoover articulates a vision for civilians on the U.S. home front in his Food in War Speech. In this speech, Hoover defined American patriotism on the home front as civilians donating food for the war effort.

The U.S. Food Administration commissioned a series of 12 paintings that toured the country based on Hoover's Food in War Speech. Each painting visualized ideas that Hoover conveyed about the reasons for food conservation. These paintings were designed to draw on American civilians' emotions and patriotism. 
In this article, I first provide a brief overview of the type of teaching advocated for in the C3 Framework by the National Council of the Social Studies (NCSS). Next, the theoretical framework for my research project is given. Then, a brief overview of the sixth grade students and the school where this research study took place is provided. Next, the procedures of my research study are discussed. Then, I give an overview of the data analysis used to examine the sixth grade students' paintings and metacognitive writing pieces. Next, I provide the results from coding students' paintings and metacognitive writing pieces. Five student examples are examined. These student examples are reflective of themes found in students' paintings and metacognitive writing pieces. Finally, a discussion section gives takeaways for how this study potentially adds to the body of literature on teaching with visual primary sources that contain political messages. The two research questions for my study are provided below.

1. In what ways, if any, did students convey political messages through creating their own painting similar to those commissioned by the U.S. Food Administration during World War I?

2. How did students through their metacognitive writing pieces articulate the ways that their paintings were designed to convey arguments for food conservation similar to those found in Hoover's Food in War Speech?

\section{LITERATURE REVIEW}

The authors of the C3 Framework advocate for middle school social studies teachers to utilize primary and secondary sources to help build students' content-area literacy, thinking, and argumentation skills (Lee \& Swan, 2013; NCSS, 2013). Social studies teachers should utilize analysis prompts that contain open-ended questions to help students deconstruct an author's arguments. This type of teaching enables students to see how individuals frame their positions on issues based on their values, biases, and beliefs (Seixas \& Morton, 2012).

Keith Barton $(2001,2018)$ argues that visual primary sources are windows into a time period. Social studies teachers need to model for students how to deconstruct visual primary sources because of the abstract thinking required (Barton, 2018; Callahan, 2013a). Visual primary sources convey ideas and emotions through imagery. Due to these various layers of meaning within visual primary sources, social studies teachers must give careful consideration to designing learning experiences for their students to analyze the complexities within a source. These learning opportunities with visual primary sources are crucial in building students' analysis skills to employ historians' heuristics (Barton, 2001, 2018; Werner, 2002).

Cory Callahan (2013a, 2013b, 2015) provides guidance to K-12 social studies teachers and social studies methods teachers to help their students have meaningful discussions with visual primary sources. He argues that teachers should provide a compelling question to drive an examination of a topic. Then, teachers should model how to analyze the contents of visual primary sources because it cannot be assumed students possess these needed skills. Next, students analyze visual primary sources in small groups to practice the analysis skills learned. 
Then, there is a class discussion where groups share their findings. Finally, students use evidence from the visual primary sources examined to answer a compelling question. Callahan (2013a) argues that the skills learned from analyzing visual primary sources are instrumental in preparing students to have critical dialogues with political messages found in campaign advertisements.

Jon Callow (2006) designed a research study where sixth grade students explored visual literacy skills through a unit examining Australian democracy. The teacher and researcher designed several lesson plans to help students deconstruct the contents of visual primary sources. These learning experiences provided students with background knowledge to create their own political pamphlet using words and imagery. The researcher interviewed students to get them to unpack their thinking about choices made while designing their political pamphlet. The excerpts from these interviews demonstrate that students were able to apply the devices used within visual primary sources to articulate why their candidate should win the election (Callow, 2006). One thing that is clear from the literature is that students need learning opportunities to explore the complex processes inherent within examining visual primary sources that contain political messages.

\section{THEORETICAL FRAMEWORK}

My research project utilized the best teaching practices for social studies education advocated for in the C3 Framework. The C3 Framework emphasizes that students should research openended questions, analyze primary and secondary sources, and use evidence to support their reasons for taking civic action (Lee \& Swan, 2013; Levinson \& Levine, 2013; NCSS, 2013). These steps argued for in the C3 Framework change the dynamics of the U.S. history classroom to be driven by inquiry-based activities.

Inquiry-based teaching practices are centered around the idea that students do research and create their own answers to a question based on evidence. With inquiry-based teaching, the social studies teacher facilitates students' research. Students use background knowledge and knowledge from their research to construct solutions to an open-ended question (Kohlmeier \& Saye, 2019; Van Hover \& Hicks, 2017). Through these processes, students go from being passive observers to active participants in their learning (Nokes, 2019).

There are several parallels in my study to that of Bickford's study (2011). In Bickford's study (2011), students studied political cartoons, selected historical images, and created their own captions to go with their chosen images to summarize the content material. The utilization of historical images and students' captions resulted in them creating their own original political cartoons. The creation of students' own original political cartoons allowed them to apply higher levels of thinking by constructing a representation of their content knowledge as discussed in Bloom's taxonomy (Bloom, 1956).

In a similar vein to Bickford's study (2011), I had a class of sixth grade students analyze a series of paintings commissioned by the U.S. Food Administration based on Hoover's Food in 
War Speech. Drawing on ideas from the literature about teaching with visual primary sources, the teacher and I started by modeling for the sixth grade students how to analyze the paintings commissioned by the U.S. Food Administration because it cannot be assumed that students possess these analysis skills (Barton, 2001, 2018; Callahan, 2013a, 2013b, 2015). After analyzing these paintings, students created their own painting based on parts of Hoover's speech but were instructed to not replicate items from the paintings examined. They had to also write a metacognitive piece explaining how their painting connected to the reasons that Hoover gave for the need of food conservation by U.S. civilians (Yancie \& Clabough, 2017). The steps of my research study similar to Bickford's study (2011) engaged students in higher levels of thinking by having them construct a representation of their content knowledge. Additionally, students articulated through their metacognitive writing piece how their painting draws on ideas from Hoover's speech in a similar way to how Callow (2006) engaged students in unpacking their thinking. This project helped to engage these sixth grade students in higher levels of thinking because they had to create a representation of content knowledge that demonstrated their understanding of how to utilize symbolic imagery. The use of symbolic imagery in students' paintings showed that they could craft similar political messages as the artists commissioned by the U.S. Food Administration during World War I.

\section{METHODOLOGY}

\section{Participants}

This research study took place in a sixth grade U.S. history classroom in a Southeastern metropolitan area. The school serves sixth through eighth grades with a student population of approximately 1,200 students. It was implemented with one of the teacher's U.S. history classes. This U.S. history class had 8 boys and 19 girls for a total population size of 27 . All of the students are white except for two Asian American students and one African American student.

\section{Procedures}

On day one of the project, the sixth grade students reviewed the devastation of Europe caused in World War I. They selected a primary source from three websites and then completed the Multi-Sensory Photograph Analysis Sheet in groups (See the Appendix for Teaching Resources with My Project). The day ended with students sharing their analysis of their selected photograph.

On day two, the teacher and I discussed the challenge that the U.S. faced entering World War I of having to help feed U.S. and Allied soldiers and civilians. Then, students read an abbreviated version of Herbert Hoover's Food in War Speech (See the Appendix for Teaching Resources with My Project). After students in small groups read this abbreviated version of Hoover's speech, they answered the following analysis prompts.

1. According to Hoover's speech, what was the purpose of the U.S. Food Administration? Use evidence to support your arguments. 
2. According to Hoover's speech, why did U.S. civilians need to take part in the food conservation effort during World War I? Use evidence to support your arguments.

3. According to Hoover's speech, what is the United States' responsibility to its allies? Use evidence to support your arguments.

4. Why do you think Herbert Hoover gave this speech? Use evidence from Hoover's speech to support your arguments.

These analysis prompts helped students examine Hoover's perspective about the role of civilians on the U.S. home front.

On day three, the teacher and I discussed how people use imagery to convey thoughts and emotions. Due to the complexity in the paintings based on Hoover's speech, we scaffolded for students how to analyze symbolic imagery in one of the paintings, The Body May Die But the Soul Is Unconquerable (Johnes, 1918). This painting is provided in the following section. The following analysis prompts were used to help students deconstruct symbolic imagery in this painting through a class discussion.

1. What stands out to you from this painting? Use evidence from the painting to support your arguments.

2. Why do you think the artist depicted the buildings and street in this manner? Explain your reasoning.

3. What is the message that the artist is trying to convey in this painting? How does the message of this painting connect to Hoover's speech? Use evidence from the painting and Hoover's speech to support your arguments.

Johnes' Painting (1918) The Body May Die but the Soul Is Unconquerable

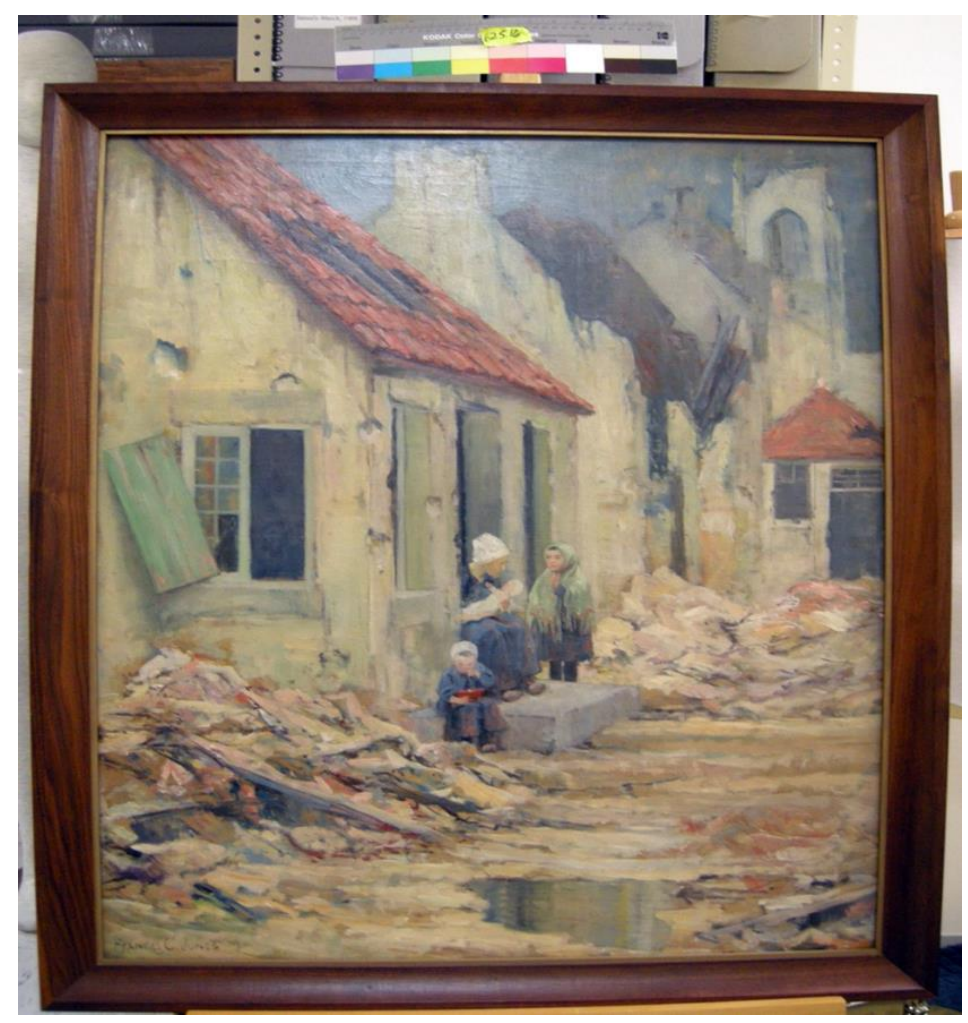


These analysis prompts helped students discuss why the artist depicted parts of the painting in a certain manner (Barton, 2018). It took the majority of the third day to discuss this painting.

After this class discussion, groups selected one of the other 11 paintings commissioned by the U.S. Food Administration and answered the analysis prompts in the following section for the rest of days three and most of day four.

1. What stands out to you from this painting? Use evidence from the painting to support your arguments.

2. Why do you think the artist utilized certain symbolic imagery in your painting? Explain your reasoning.

3. What is the message that the artist is trying to convey in this painting? How does the message of this painting connect to Hoover's speech? Use evidence from the painting and Hoover's speech to support your arguments.

This activity allowed students an opportunity to apply analysis skills learned about visual primary sources (Callahan, 2015). After groups answered the analysis prompts, there was a class discussion where groups shared the symbolic imagery of their painting.

On day five, the teacher gave the instructions below for the summative assessment that students completed individually.

Assume the role of an artist commissioned by the U.S. Food Administration to create a painting based on a portion of Herbert Hoover's Food in War Speech. Create a painting that uses symbolic imagery to discuss a portion of Hoover's speech. Your painting needs to be different from the paintings already analyzed.

In addition to your painting, please write a metacognitive piece for your painting to answer the following questions. What is the overall message of your painting? What symbolic imagery did you use in your painting? How did your painting use symbolic imagery to connect to a portion of Hoover's Food in War Speech?

It took the students the rest of days five and six to finish their painting and write and edit their metacognitive piece.

\section{Data Analysis}

There were two sets of data examined from this research study: students' paintings and their metacognitive pieces. Students' paintings and metacognitive writing pieces were coded using qualitative content analysis with inductive and deductive elements (Elo \& Kyngas, 2007; Kline, 2008; Krippendorff, 2013; Maxwell, 2010; Zhang \& Wildemuth, 2009). During open coding, observations of and outliers to patterns that emerged during open coding were created and synthesized into testable codes for axial coding. With students' paintings, I had to note how they used symbolism within the imagery in their painting similar to the series of paintings commissioned by the U.S. Food Administration. During the step of axial coding, all students' paintings and metacognitive writing pieces were examined to note the presence, absence, and frequency of the codes. Data were compiled and analyzed. Patterns are discussed, and their 
significance is articulated in subsequent sections. The subsequent sections contain samples from student work that illustrate emergent themes from their paintings and metacognitive writing pieces. The student paintings and metacognitive pieces discussed reflect items commonly found in all students' work. Pseudonyms are given for all students.

There were four themes that emerged from analyzing students' paintings and metacognitive writing pieces: connection with how food donations by civilians directly helps U.S. soldiers on the front lines, U.S. civilians need to grow food for the war effort, some people are not taking part in the U.S. food conservation effort, and dire need for food donations to civilians of our European allies. This shows that students' paintings reflected the same themes found in the 12 paintings commissioned by the U.S. Food Administration. Each of these themes will be explored in subsequent sections through a student's painting and metacognitive writing piece. Additionally, there was one student that talked about the U.S. Food Administration in such novel ways that a brief examination of her painting is warranted.

\section{RESULTS}

\section{Connecting how Food Donations by U.S. Civilians Directly Helps U.S. Soldiers}

The most common theme of students' paintings was the focus on how civilians on the U.S. home front contributing to the food conservation effort helped soldiers fighting the war. There were 11 students who focused on this theme. I will use Karen's painting as an example to show the connections between civilians' actions on the U.S. home front to the soldiers' successes on the front lines.

\section{Karen's Painting}

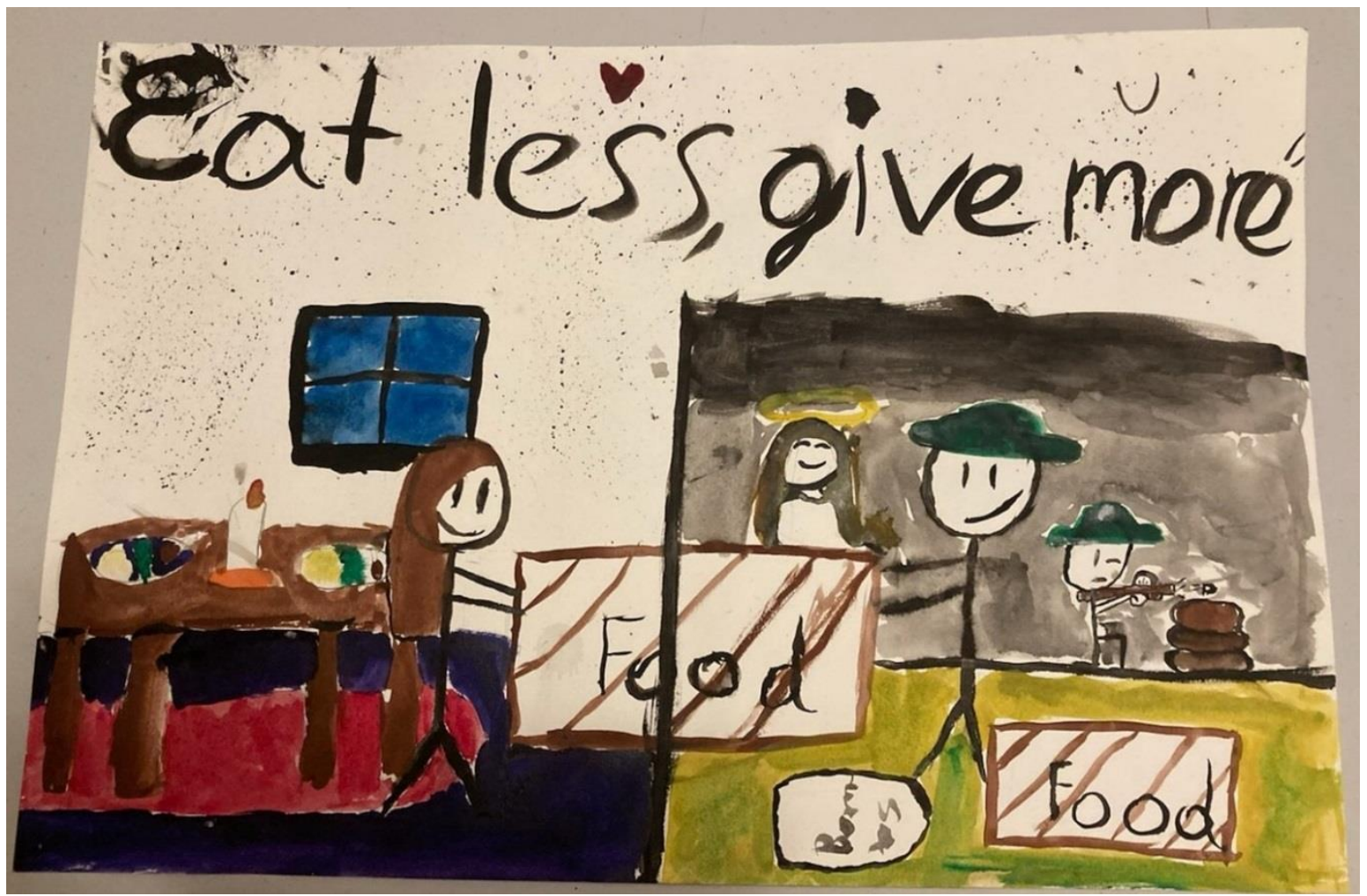

Karen included two main images in her painting. On the left-hand side of Karen's painting, she shows a person at a dinner table with some food on it, but this person is giving 
some food to soldiers on the right-hand side of the painting. On the right-hand side of Karen's painting, the focus is on U.S. soldiers on the front lines. Karen is implying that the food donations being made by civilians are being used by soldiers on the front lines. She also utilizes strategically-placed words and phrases in her painting. A viewer's eye goes to the phrase at the top of Karen's painting: "Eat less, give more." It comes across that the giving in Karen's painting will help soldiers be successful on the front lines, which is an argument made in Hoover's Food in War Speech.

Karen also did a good job explaining through her metacognitive writing piece about the choices that she artistically made in her painting. She summarized the main message of her painting in the metacognitive writing piece with the phrase "Eat less, give more." Another item mentioned in Karen's metacognitive writing piece is about her choice to show an angel smiling directly above the middle of the painting where the civilian is handing the soldier a box of food. It can be inferred that this is a morally good action. Karen also connects the contents of her painting to Hoover's Food in War Speech based on his argument that civilians should eat less food so they "can give a little more instead of eating it themselves." While Karen's metacognitive writing piece was short, she did succinctly convey how her painting connects to ideas in Hoover's speech about civilians' actions on the home front helping U.S. soldiers on the front lines.

\section{The Role U.S. Civilians Play through Food Conservation Efforts}

Nine students in their paintings focused on how civilians' actions of growing and conserving more food would help European allies. I use Erin's painting as an example to depict the connections between civilians' actions with food conservation on the U.S. home front to addressing food shortages with our allies abroad.

\section{Erin's Painting}

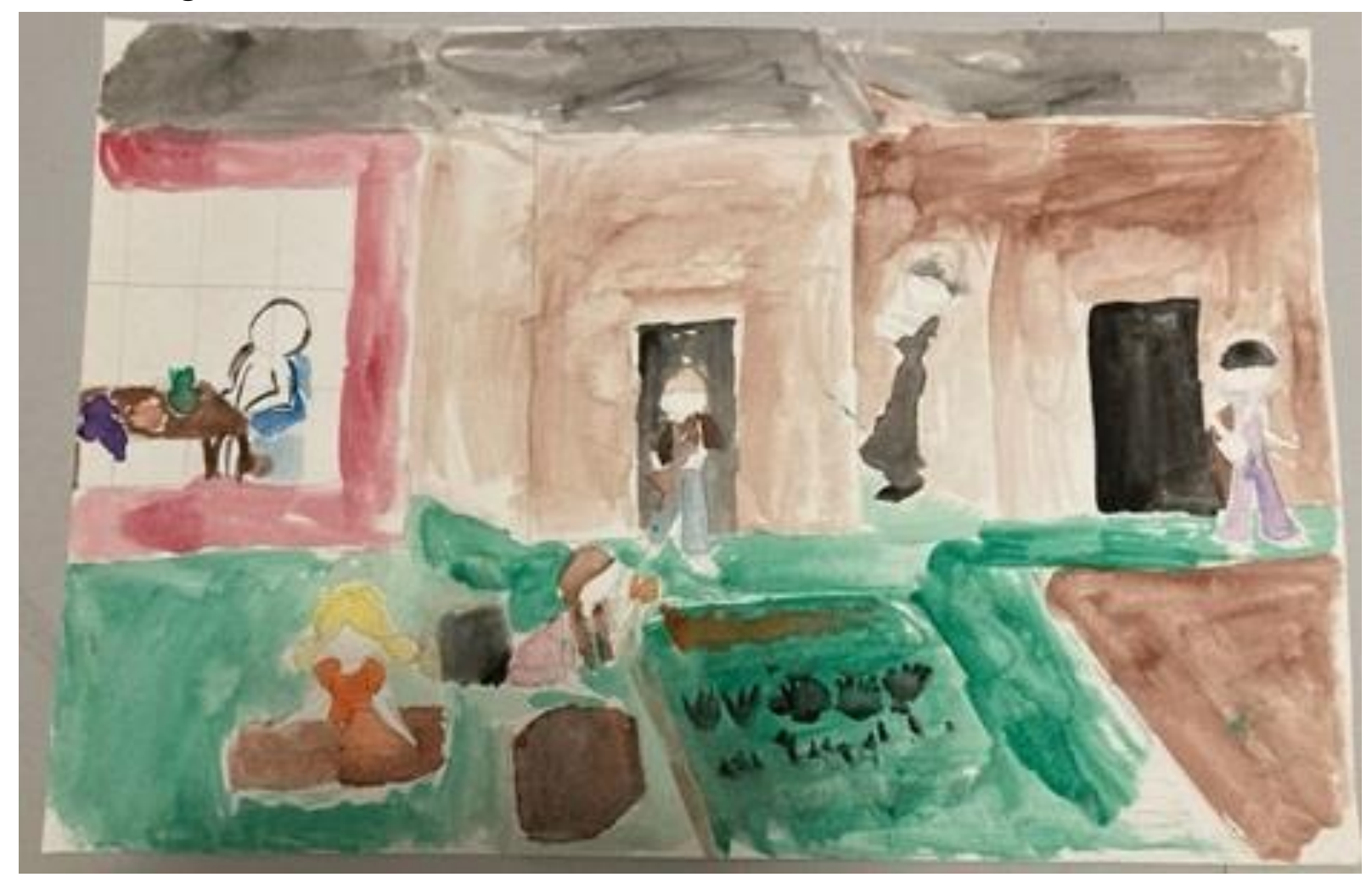


Erin's painting contains a lot of images with symbolic meaning connected to Hoover's speech. First, several people are included that are taking actions designed to help in the food conservation effort. There is a blonde-haired girl shown at the bottom working a garden. There are several people carrying boxes of food, and based on Erin's description in her metacognitive writing piece, these people are about to go donate these boxes of food. There is also a person shown away from the other people that is not taking part in the food donation effort, which eludes to Hoover's statements that some U.S. citizens on the home front are not taking part to help in the war effort.

Erin did a good job unpacking arguments in her metacognitive writing piece. She states that the following is the overall message of her painting.

The message of my painting is that all people should help out for a major cause. If you sit there and do nothing, that is one less box of food to the homeless and one less package of supplies for our soldiers. Helping with the war effort helps us win the war.

To convey this message, Erin employs a variety of symbolic images focusing on people planting and donating food. She did this to tell her audience "where the food is going." One person is mentioned to not be taking part in the food conservation effort to show how this person reflects the hoarding that Hoover argues should not be done because as Erin states "this person is not helping at all."

Erin also provided the quote from Hoover's speech that was the focus of her painting: "The success of the war effort is dependent on the sacrifices of U.S. citizens on the home front." She is one of the few students that actually connected her painting to a direct quote from Hoover's speech. Erin justifies how the message of her painting "that all people should help out for a major cause" connects to the direct quote from Hoover's speech.

\section{Some People Are Price Gouging with Food}

There were three students who focused their paintings on price gouging with food. Hoover discusses in his speech that American civilians engaging in price gouging were not patriotic and were more focused on their own self-interests instead of helping with the war effort. I will use Brook's painting to examine the theme conveyed in students' paintings of price gouging during the war. 


\section{Brook's Painting}

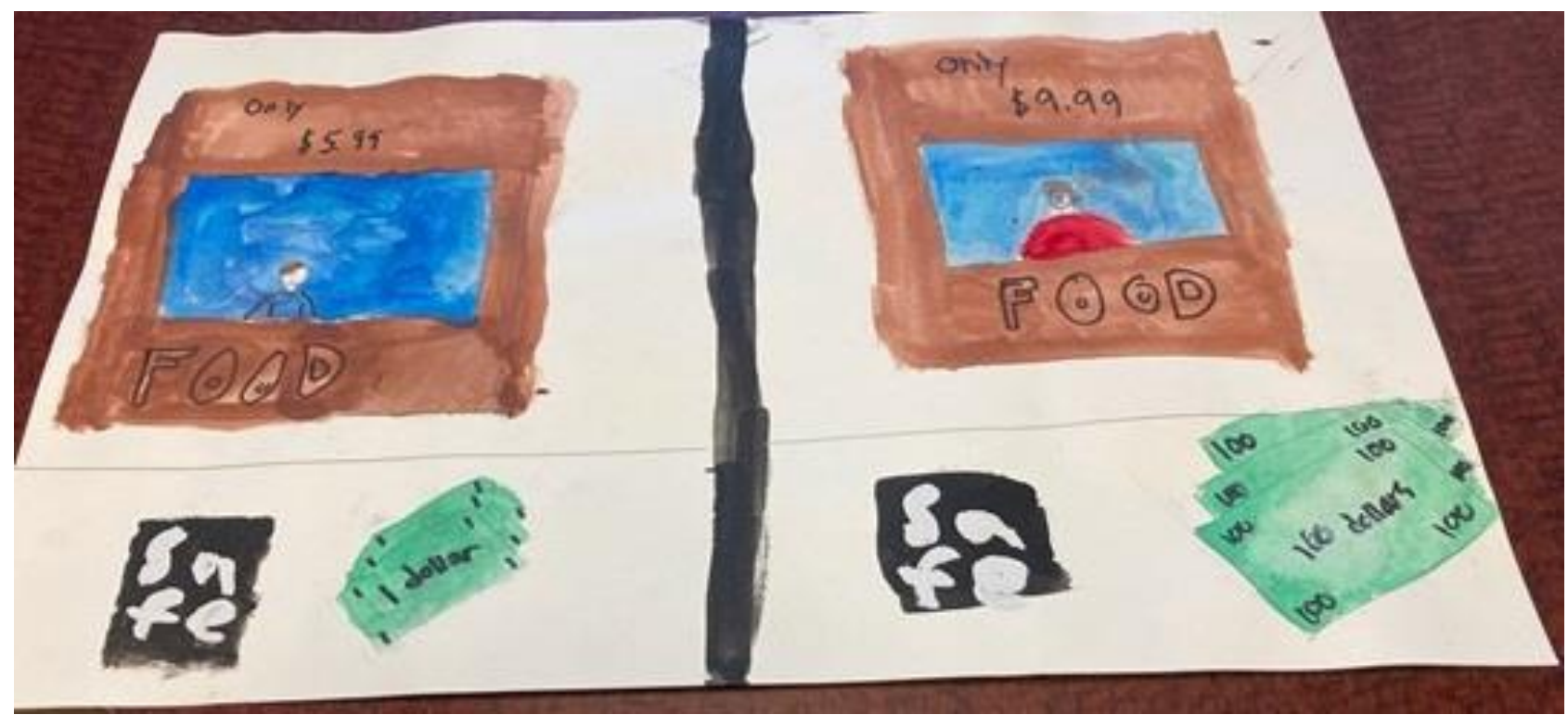

In Brook's painting, she has two main images. The image on the left-hand side shows someone selling food for $\$ 5.99$, and on the right-hand side, there is another person selling food at an inflated price of $\$ 9.99$. The booths where these two people are selling food are the same, which Brook uses to convey that the person on the right-hand side is price gouging. The person on the right-hand side is price gouging to earn more profits. This can be seen in Brook's image with the person on the right having more dollars below the booth than the individual on the left-hand side of the painting.

Brook conveyed in her metacognitive writing piece that the overall message of her painting is that "no one should use the war for their benefit. Price gouging is when you raise your prices for your own goals. Some people did this during World War I. Herbert Hoover did not approve of price gouging." She said the symbolic imagery in her painting included the fact that, "I used money to show the benefits of raising your prices even though it is wrong. It also represents the differences in the pay check." Brook's symbolic imagery reflects the arguments made by Hoover about the unethical practices of price gouging during World War I. Brook connects her painting to Hoover's arguments about price gouging even though she did not quote any part of Hoover's speech. She says "that Hoover says price gouging is bad and effects the war effort. During this time, people needed to help the soldiers, but some people did not care. They raised their prices for the benefit of themselves." Brook's statement shows that she agrees with Hoover's arguments about price gouging and regards price gouging as selfish and unpatriotic.

\section{Dire Need for Food Donations to European Allies}

Three students focused their paintings on conveying the reasons for why food donations were needed for our European allies. I will use Martin's painting as an example that captures how these three students depicted the urgent need for food donations to our allies. 


\section{Martin's Painting}

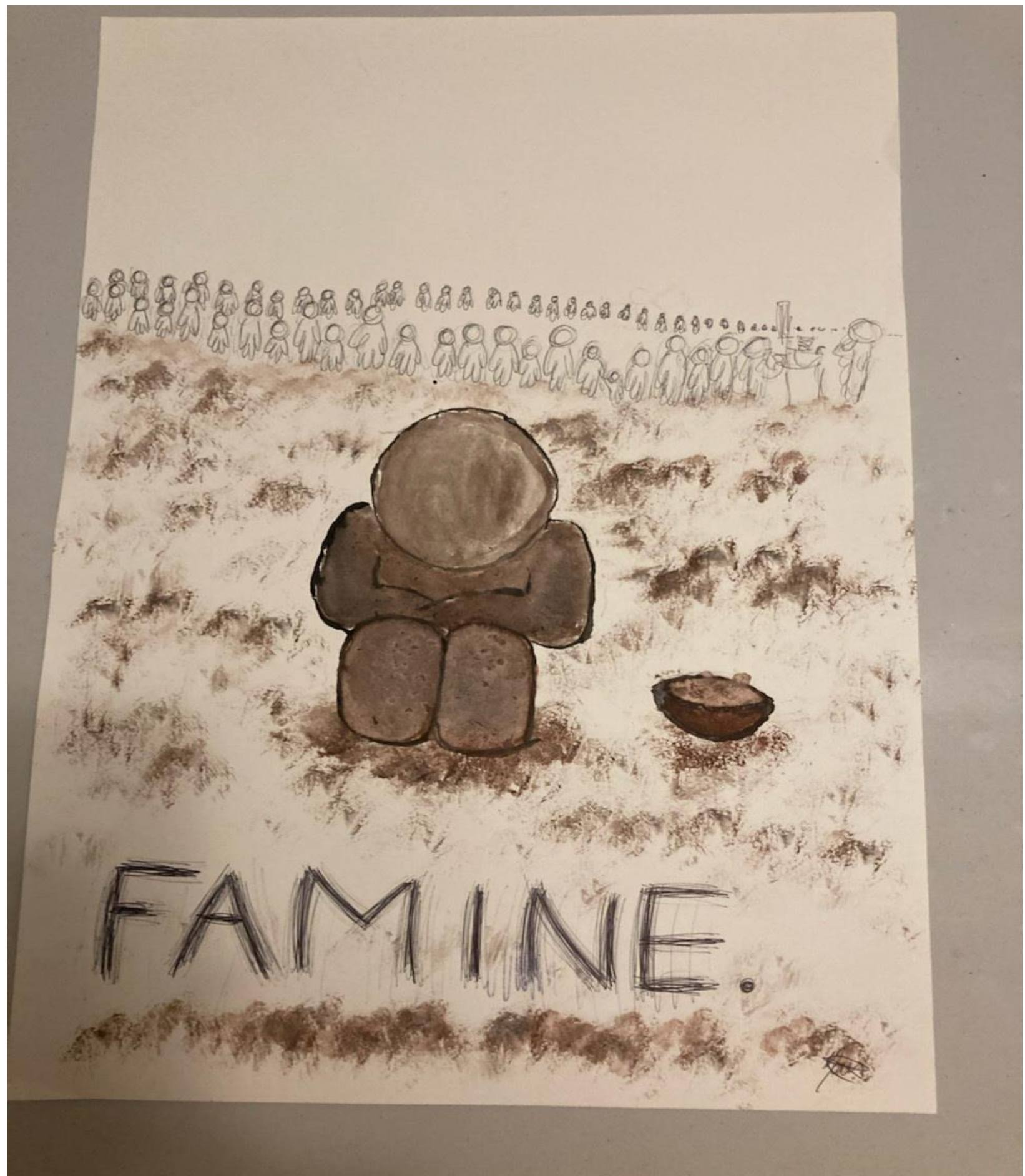

Martin painted a person in the middle of his image with dreary colors to show the sad state of people in Europe with no food. Next to the person in the middle of Martin's painting is an empty bowl of food symbolizing the food shortage Hoover discusses in his speech. In the background, Martin added a lot of people waiting in a food line. The dreary colors convey the sad state of Europe in World War I. These emotions are driven home by the one word added at the bottom of Martin's painting with a black pen in all capital letters: FAMINE. The use of this one word in conjunction with the bleak images captures how Hoover discusses Europe. Martin's painting shows that he was able to analyze how Johnes' painting (1918) depicted the impact of 
World War I on civilians and used similar symbolic imagery to cause American civilians to want to donate to the food effort. Martin works to show through the imagery of his painting how a viewer can empathize with what the civilians of our allies were going through in World War I. It is important for social studies teachers to frame topics so that students can connect on a personal level with content being explored (Endacott \& Brooks, 2013).

Martin did an excellent job articulating his thoughts through the metacognitive writing piece about the choices that he made in his painting. He says the message of his painting was to "show how World War I impacted citizens of England and our other allies." There are multiple examples of symbolic imagery employed by Martin containing political messages to cause U.S. civilians to donate food for the war effort. Martin mentions he "used dark colors to capture the sad mood in Europe during World War I along with the empty bowl and long food line to convey the food shortage in Europe." He also points out his painting connects to parts of Hoover's speech. Specifically, Martin says his painting "shows the long food lines in England that Hoover mentioned in the fifth paragraph of his speech." This demonstrates that Martin was able to accurately apply parts of Hoover's speech through the political messages within his painting.

\section{The U.S. Food Administration's Leadership for the Food Relief Effort of European Allies}

Students' paintings mainly fell into the four themes already discussed. Eleanor's painting is the only one that focused solely on the U.S. Food Administration.

\section{Eleanor's Painting}

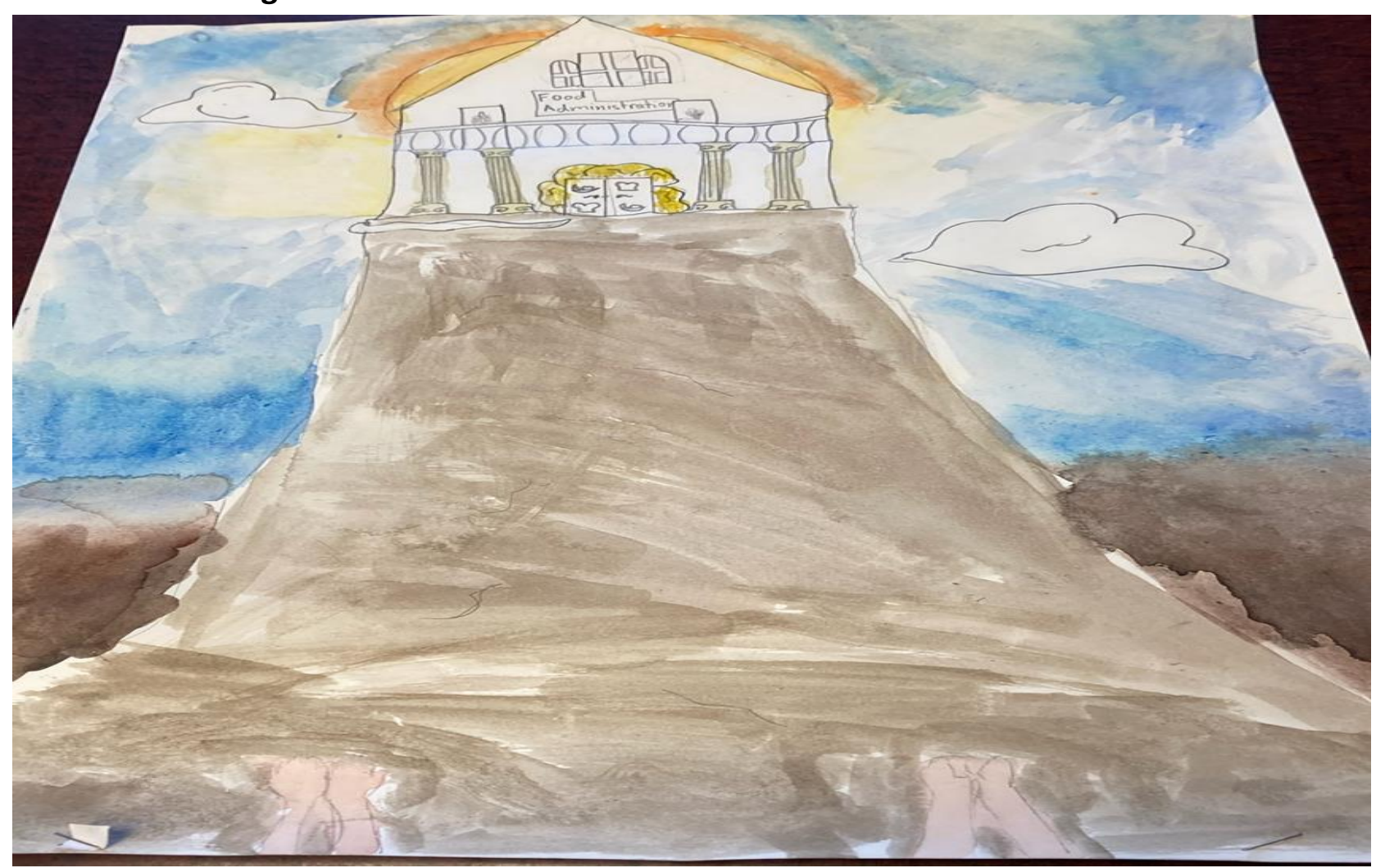

There are several elements in Eleanor's painting that highlight the impact of the U.S. Food Administration in feeding Allied civilians. First, there is a building labeled at the top of a 
hill as "Food Administration." The placement of this building at the top of the hill denotes its importance. Inside this building, Eleanor put some food, which shows the role of the U.S. Food Administration to distribute food. A closer examination of Eleanor's painting adds meaning to the role of the U.S. Food Administration for food relief efforts. In the bottom center of the painting, there are two pairs of hands lifted up toward the building marked "Food Administration." This shows how some people were dependent on the U.S. Food Administration. Finally, Eleanor's color in her painting is worth noting. The color use near the top of the painting uses very warm colors with the light blue sky and the yellow and orange colors behind the building, which looks like the sun. The color choices were used by Eleanor to show the positive impact of the U.S. Food Administration on people's lives.

In her metacognitive writing piece, Eleanor discusses the overall message of her painting in religious terms.

The U.S. Food Administration is like a savior and the cure, hence the light and clouds, but below the mountain are the hungry people from Belgium. The mountain symbolizes how it is hard for them to get there. Also, the sky at the bottom is darker to show that the people in Belgium are in dark times.

Eleanor does a great job of discussing the use of color to capture the mood and stark realities that people in Belgium faced during World War I. She does not quote Hoover's speech but does paraphrase certain parts of it.

Hoover talks about how the U.S. Food Administration is a primary source in feeding those in Belgium. That's the reason for the sun behind the U.S. Food Administration building. He also talks about how awful it is in Belgium. This is shown by the dark colors at the bottom of my painting.

The religious overtones used by Eleanor are an outlier in the students' paintings as is her discussion of the U.S. Food Administration and how this organization would be perceived by the Belgium people. Due to time constraints on the project, the teacher and I did not have time to discuss how the Belgium people reacted to the food relief efforts by the U.S. Food Administration, and most notably the leadership efforts by Herbert Hoover to this organization. This is an example of inferential thinking that Eleanor made in this project on her own that accurately reflects how Hoover was valued by the Belgian government as demonstrated by the excerpt below.

To the foreign minister and his colleagues, Hoover's offhand remark provided an opening. That evening at the royal cottage, King Albert hosted a dinner for his American guest; the visiting Belgian Cabinet officials also attended. At the end as Hoover was about to leave for Boulogne, the king suddenly addressed him. The monarch declared that he wished to express a "debt of gratitude" that could never be repaid. The Belgian people he said, "would always turn to Hoover as their savior in times of national calamity. Albert thereupon state that he had created a new order and that Hoover would be its only 
member. He then conferred upon Hoover the title "Ami de las Nation belge"---- "Friend of the Belgian Nation." (Nash, 1996, p. 463)

Again, this connection was made by Eleanor. The teacher and I did not cover this content with the class. It can be presumed that Eleanor probably had no knowledge of the quote from Nash's book (1996) that also associated the word "savior" with Hoover and the work of the U.S. Food Administration to provide food relief for Belgium. This is a text to world connection that Eleanor made based on a previous life or educational experiences. While the origins of Eleanor's connection of the U.S. Food Administration as a "savior" similar to the historical anecdote shared in Nash's book (1996) cannot be ascertained, it does show that she applied disciplinary inferential thinking skills based on historical issues and events being studied in this project (Nokes, 2013).

\section{DISCUSSION}

The findings from this research study support arguments from the literature that with the appropriate scaffolding even younger students can analyze visual primary sources (Barton, 2001, 2018; Callahan, 2013a, 2013b, 2015). With this research project, the teacher and I modeled for students on day three how to analyze the symbolic imagery with one of the paintings. Students practiced these analysis skills on days three and four through group work to analyze another one of the paintings commissioned by the U.S. Food Administration. It was clear from circulating the room while students were analyzing a painting in small groups that they still needed help deconstructing the meaning of the symbolic imagery within each painting. Even when the groups presented their painting at the end of the fourth day, the teacher and I still had to use supporting questions to further help the students unpack the meaning of their painting.

Similar to the work of Bickford (2011) and Callow (2006), the sixth grade students in my research project created a representation of their content knowledge through their painting. One item that differentiates my research study from others in the literature was the focus on students completing a metacognitive writing piece. Callow (2006) did interview the sixth grade students in his project about choices made in their political pamphlets. However, the sixth grade students in my research project did a writing assignment to unpack the choices made in their painting. These students on average wrote a short paragraph response to each of the three questions posed in the metacognitive writing prompt.

Students' metacognitive writing pieces contained evidence of how they were able to articulate the parallels of arguments for food conservation in their paintings to those found in Hoover's speech. The third analysis prompt in the metacognitive writing pieces asked students to connect their painting to Hoover's speech. The majority of the students summarized how their paintings connected to Hoover's speech as opposed to directly quoting Hoover's speech. This reflects the type of evidence-based teaching advocated for in the C3 Framework because students are supporting their arguments based on primary sources examined (NCSS, 2013). Social studies teachers need to carefully and thoughtfully design writing prompts for their 
students to use evidence to support their arguments (Monte Sano, 2012). It appears more modeling is needed by the teacher to help students feel comfortable with directly quoting primary sources examined in their metacognitive writing pieces.

It is worth noting several students consistently used words and phrases with their paintings. The teacher and I did not tell the students to include these words and phrases in their paintings. This was an artistic choice made by the students to convey messages within their paintings. Karen and Martin's paintings discussed in earlier sections both used limited amount of words to convey the messages within their paintings. Similar to Bickford's study (2011), students constructed a multimodal representation of their content knowledge through words and images (Dalton, 2015). These multimodal representations of students' messages in their paintings are encouraging since this reflects the way most political messages through visual sources are constructed. The ability to construct political messages in this way helps prepare students as future democratic citizens to deconstruct similar political messages (Sperry \& Baker, 2016).

Due to time constraints, my research project was limited to six days. Therefore, the focus of this project was on helping the students gain the ability to analyze and create their own visual primary sources containing political messages. This caused there to be missed learning opportunities. The students consistently conveyed traditional definitions of patriotism in their paintings and metacognitive writing pieces where U.S. citizens are loyal to the leaders and causes during times of war (Westheimer, 2008). This is not surprising since Hoover's Food in War Speech articulates a more traditional definition of patriotism, and many of the students come from conservative families in a Southern state that also agree with Hoover's beliefs about patriotism.

A future study that builds on this project could replicate this research project but also add the additional component of how women and supporters of the suffragette movement demonstrated a different version of patriotism by protesting for the right to vote during World War I. It is important for students to realize that the three major wars of the 20th century, World War I, World War II, and the Vietnam War, were all protested by a portion of civilians on the U.S. home front. Social studies teachers can use excerpts from Zimet's trade book (2018) Roses and Radicals: The Epic Story of How American Women Won the Right to Vote to expose students to how women protested during World War I for the right to vote.

Many Americans have defined patriotism in different ways, especially during times of war (Westheimer, 2008). The addition of this component helps students grasp the divergent ways that Americans define patriotic actions. It is important for students to discuss these competing definitions of American patriotism since this is still a controversial issue in contemporary U.S. society as demonstrated by the protests of the 2020 summer about the deaths of George Floyd and Breonna Taylor (Carrega, 2020; Searcey \& Zucchion, 2020). Students need learning opportunities to deconstruct how American patriotism is defined and argued based on images from contemporary protests about issues of race. The social studies classroom 
is one of the few safe spaces that our students have to examine competing beliefs about controversial public issues (Kawashima-Ginsberg \& Junco, 2018).

\section{CONCLUSION}

Middle school students need support deconstructing the symbolic images within visual primary sources. However, with the proper scaffolding, students can analyze visual primary sources. It took two class periods for the students in my study to gain the knowledge and ability to analyze political messages through the symbolic imagery of the 12 paintings commissioned by the U.S. Food Administration, but this was time well spent. The students in my research study constructed their own political messages in their painting similar to those found in the visual primary sources examined. They were also able to articulate how and why symbolic imagery was employed to convey certain political messages. The ability to analyze and interact with political messages through visual sources is an important skill to prepare our students to be future democratic citizens (Clabough, 2017).

\section{REFERENCES}

Barton, K. (2001). A picture's worth: Analyzing historical photographs in the elementary grades. Social Education, 65(5), 278-283.

Barton, K. (2018). Historical sources in the classroom: Purpose and use. HSSE Online, 7(2), 111.

Bickford, J.H. (2011). Examining original political cartoon methodology: Concept maps and substitution lists. Social Studies Research and Practice, 6(3), 65-80.

Bloom, B. (1956). Taxonomy of educational objectives, handbook I: The cognitive domain. David McKay Co Inc.

Callahan, C. (2013a). Analyzing historical photographs to promote civic competence. Social Studies Research and Practice, 8(1), 77-88.

Callahan, C. (2013b). Thinking historically about the Depression Era. Social Studies Research and Practice, 8(2), 25-42.

Callahan, C. (2015). Creating or capturing reality? Historical photographs of the Progressive Era. The Social Studies, 106(2), 57-71.

Callow, J. (2006). Images, politics, and multiliteracies: Using a visual metalanguage. Australian Journal of Language and Literacy, 29(1), 7-23.

Carrega, C. (2020, September 9). A grand jury will soon hear case of Breonna Taylor's killing. CNN News. https://www.cnn.com/2020/09/09/us/breonna-taylor-grandjury/index.html

Clabough, J. (2017). Helping develop students' civic identities through exploring public issues. The Councilor: A Journal of the Social Studies, 78(2), 1-9.

Dalton, B. (2015). Level up with multimodal composition in social studies. The Reading Teacher, 68(4), 296-302. 
Elo, S., \& Kyngas, H. (2007). The qualitative content analysis process. JAN Research Methodology, 62(1), 107-115.

Endacott, J., \& Brooks, S. (2013). An updated theoretical practical model for promoting historical empathy. Social Studies Research and Practice, 8(1), 41-58.

Johnes, F. (1918). The body may die but the soul is unconquerable. The U.S. Food Administration.

Kawashima-Ginsberg, K., \& Junco, R. (2018). Teaching controversial issues in a time of polarization. Social Education, 82(6), 323-329.

Kline, W. (2008). Developing and submitting credible qualitative manuscripts. Counselor Education and Supervision, 47, 210-217.

Kohlmeier, J., \& Saye, J. (2019). Examining the relationship between teachers' discussion facilitation and their students' reasoning. Theory \& Research in Social Education, 47(2), 176-204.

Krippendorff, K. (2013). Content analysis: An introduction to its methodology (3rd ed.). Sage Publishing.

Lee, J. \& Swan, K. (2013). Is the Common Core good for social studies? Yes, but... Social Education, 77(6), 327-330.

Levinson, M. \& Levine, P. (2013). Taking informed action to engage students in civic life. Social Education, 77(6), 339-341.

Mason, L. (2015). Media literacy: Analyzing political commercials. Social Studies Research and Practice, 10(2), 73-83.

Maxwell, J. (2010). Using numbers in qualitative research. Qualitative Inquiry, 16(6), 475-482.

Miller, J. (2018). WW I Crusaders. Mildbrown Press.

Monte-Sano, C. (2012). What makes a good history essay? Assessing historical aspects of argumentative writing. Social Education, 76(6), 294-298.

Mullendore, W.C. (1941). History of the United States Food Administration 1917-1919. Stanford University Press.

Nash, G. (1988). The life of Herbert Hoover: The humanitarian, 1914-1917. W.W. Norton \& Company.

Nash, G. (1996). The life of Herbert Hoover: Master of emergencies, 1917-1918. W.W. Norton \& Company.

NCSS. (2013). The college, career, and civic life framework for social studies state standards: Guidance for enhancing the rigor of $K-12$ civics, economics, geography, and history. Author.

Nokes, J. (2013). Building students' historical literacies: Learning to read and reason with historical texts and evidence. Routledge.

Nokes, J. (2019). Teaching, history, learning citizenship: Tools for civic engagement. Teachers College Press. 
Searcey, D., \& Zucchion, D. (2020, June 6). Protests swell across America as George Floyd is mourned near his birthplace. The New York Times.

https://www.nytimes.com/2020/06/06/us/george-floyd-memorial-protests.html

Seixas, P. \& Morton, T. (2012). The big six historical thinking concepts. Nelson College Indigenous.

Sperry, C. \& Baker, F. (2016). Media literacy. Social Education, 80(3), 183-185.

Van Hover, S., \& Hicks, D. (2017). Social constructivism and student learning in social studies. In M. M. Manfra, \& C. M. Bolick (Eds.), The Wiley handbook of social studies research (pp. 270-318). John Wiley \& Sons.

Werner, W. (2002). Reading visual texts. Theory \& Research in Social Education, 30(3), 401428.

Westheimer, J. (2008). Thinking about patriotism. Educational Leadership, 65(5), 48-54.

Yancie, N. \& Clabough, J. (2017). Enabling gifted students to actualize their potential through social studies writing activities. In G. Hickey \& J. Clabough (Eds.), Digging deeper: Activities for enriching and expanding social studies instruction $K-12$ (pp. 217-232). Information Age Publishing.

Zhang, Y., \& Wildemuth, B. (2009). Qualitative analysis of content. In B. Wildemuth (Ed.), Applications of social research methods to questions in Information and Library Science (pp. 308-319). Libraries Unlimited.

Zimet, S. (2018). Roses and radicals: The epic story of how American women won the right to vote. Puffin Books. 
Appendix for Teaching Resources with My Project

Multi-Sensory Photograph Analysis

Photograph title or

description

Level I: Two-Dimensional Experience

What do you notice?

\begin{tabular}{|l|l|}
\hline Observation & Inference \\
\hline & \\
& \\
& \\
\hline
\end{tabular}

Level II: Three-Dimensional Experience

Select a location or position to explore

\begin{tabular}{|l|l|}
\hline Scents & Sounds \\
\hline & \\
& \\
& \\
\hline
\end{tabular}

Level III: Three-Dimensional Experience

Select a location or position to explore

\begin{tabular}{|l|l|}
\hline Touch & Taste \\
\hline & \\
& \\
& \\
\hline
\end{tabular}




\section{Abbreviated Version of Herbert Hoover's Food in War Speech}

The Food Administration in the United States is an instrument of our war effort. Its primary concern is feeding our own people and those of the Allies. This guarantees the strength of all men, women, and children on the home front and abroad.

The question of meeting the food needs for the war is mainly about determining the amount of food we need at home so extra food can be shipped to our soldiers and allies. The United States is the most important part of meeting the food needs not only of our soldiers but the soldiers and citizens of Allied countries. This is because we can ship our extra food to the war effort, plant more food at home, and reduce our waste of food.

The reduction of food use in the United States is important for the war effort to be successful. We have to reduce the food eaten in the United States a little bit to help the soldiers and citizens of our allies. This means that we are going to have to increase the exports that we send to the Allies with food such as wheat and eat a little less of such food items as wheat.

The success of the war effort is dependent on the sacrifices of U.S. citizens on the home front. This happens through the everyday actions of U.S. citizens and working with local community groups to meet the needs of the war effort. The food producers in the United States have also worked hard to meet the food needs of our soldiers and the soldiers and citizens of the Allies.

One group that we have had to feed is the needy displaced women and children in Belgium impacted by the destruction caused by the German army. We have had this duty for the last three years. Additionally, the food lines for the poor in England, France, and Italy have been worse this past winter. This has really put a strain on the governments of our European allies. This should pull on our heart strings. These food shortages pose a threat to our success in war. U.S. citizens need to volunteer to help with the war effort by eating only what is needed and through saving extra food for the war effort.

I do not believe that anyone has the right to profit from the war through high increases in prices of foods or supplies. Price gouging reflects poorly on the American character and values. If our citizens engaged in price gouging, the United States would be no better than our German enemies. People price gouging hurt our soldiers involved in the war.

The success of the Food Administration is largely because of volunteer cooperation of U.S. citizens on the home front. With our current war, it will be successful based on the actions of men, women, and children in the United States. 